\title{
Comparison of wildlife and captivity rattlesnakes (Crotalus durissus terrificus) microbiota ${ }^{1}$
}

\author{
Rui S. Ferreira Junior ${ }^{2,3 *}$, Amanda K. Siqueira ${ }^{4}$, Michelle V. Campagner², \\ Tatiana Salerno ${ }^{4}$, Taíssa C.S. Soares ${ }^{4}$, Simone B. Lucheis ${ }^{5}$, Antonio C. Paes ${ }^{4}$ \\ and Benedito Barraviera ${ }^{2,3}$
}

\begin{abstract}
Ferreira Junior R.S., Siqueira A.K., Campagner M.V., Salerno T., Soares T.C.S., Lucheis S.B., Paes A.C. \& Barraviera B. 2009. Comparison of wildlife and captivity rattlesnakes (Crotalus durissus terrificus) microbiota. Pesquisa Veterinária Brasileira 29(12):999-1003. Centro de Estudos de Venenos e Animais Peçonhentos, Universidade Estadual Paulista, Fazenda Experimental Lageado, Rua José Barbosa de Barros 1780, Botucatu, SP 18610-307, Brazil. E-mail: rseabra@cevap.org.br

The study evaluated and compared the aerobic microbiota from the oral cavity, cloaca and venom of Crotalus durissus terrificus snakes, recently caught from the wild and kept under quarantine (WQ), individual captivity (IC) and collective captivity (CC). Antimicrobial drug effectiveness on isolated agents also was assayed. From group I, II and III were isolated, respectively, 29 (63.04\%), $38(90.48 \%)$ and $21(42.86 \%)$ microorganisms from the cloaca; $15(32.61 \%), 3(7.14 \%)$ and 25 (51.02\%) microorganisms from the oral cavity; and, 2 (4.35\%), $1(2.38 \%)$ and $3(6.12 \%)$ microorganisms from venom. The most frequent bacteria were Pseudomonas aeruginosa, Proteus vulgaris and Morganella morganii, with sensitivity to amikacin, gentamicin, norfloxacin, sulfazotrin and tobramycin. Snakes kept in semi-open captivity exhibited the fewest microorganisms in oral cavities, perhaps due to the environment in captivity, with different temperature gradients, running water, absence of daily handling, circulating air, possibility of moving around, daily cleaning, and sunlight access.
\end{abstract}

INDEX TERMS: Crotalus durissus terrificus, microbiota, captivity, antimicrobial susceptibility, snakes.

RESUMO.- [Comparação da microbiota de cascavéis (Crotalus durissus terrificus) de vida-livre e cativeiro.] Este estudo avaliou e comparou a microflora aeróbica da cavidade oral, cloaca e veneno de serpentes Crotalus durissus terrificus recém-capturadas da natureza e man-

\footnotetext{
${ }^{1}$ Received on December 7, 2009.

Accepted for publication on December 15, 2009.

${ }^{2}$ Centro de Estudos de Venenos e Animais Peçonhentos (CEVAP), Universidade Estadual Paulista (Unesp), Fazenda Experimental Lageado, Rua José Barbosa de Barros 1780, Botucatu, SP 18610-307, Brazil. * Corresponding author: rseabra@cevap.org.br

${ }^{3}$ Faculdade de Medicina de Botucatu (FMB), Unesp, Distrito de Rubião Junior s/n, Botucatu, SP 18618-000.

${ }^{4}$ Departamento de Higiene Veterinária e Saúde Pública, Faculdade de Medicina Veterinária e Zootecnia (FMVZ), Unesp, Distrito de Rubião Junior s/n, Botucatu, SP 18618-000.

${ }^{5}$ Agência Paulista de Tecnologia e Agronegócio (APTA/SAA), Pólo Centro-Oeste, Unidade de Pesquisa de Bauru, Av. Rodrigues Alves 4040, Bauru, SP 17013-000, Brazil.
}

tidas sob quarentena (WQ), mantidas em cativeiro coletivo (CC) e em cativeiro individual (IC). A eficácia de drogas antimicrobianas de agentes isolados foi também avaliada. Foram isolados microorganismos dos grupos I, II e III respectivamente: 29 (63.04\%), $38(90.48 \%)$ e 21 (42.86\%) da cloaca; 15 (32.61\%), 3 (7.14\%) e $25(51.02 \%)$ da cavidade oral, e finalmente $2(4.35 \%), 1(2.38 \%)$ e 3 $(6.12 \%)$ do veneno. As bactérias mais frequentes foram Pseudomonas aeruginosa, Proteus vulgaris e Morganella morganii, com sensibilidade para amikacina, gentamicina, norfloxacina, sulfazotrina e tobramicina. Serpentes mantidas no cativeiro semi-aberto mostraram menor número de agentes infecciosos em cavidade oral, talvez devido ao ambiente de cativeiro com diferentes gradientes de temperatura, água corrente, ausência de manejo diário, ampla circulação de ar, possibilidade de movimentação pelos animais, limpeza diária e acesso ao Sol.

TERMOS DE INDEXAÇÃO: Crotalus durissus terrificus, microbiota, cativeiro, susceptibilidade antimicrobiana, serpentes. 


\section{INTRODUCTION}

The oral cavity of poisonous and non-poisonous snakes is colonized by a large variety of anaerobic and aerobic microorganisms (Arroyo et al. 1980, Blaylock 2001).

The stress that snakes normally suffer in the processes of venom extraction handling and artificial environment adaptation has a direct impact on their health. This dynamic interferes in ophidian oral microbiota, which may, in turn, alter the quantity and potency of the venoms (Soveri \& Seuna 1986).

The microbiota of snakes in captivity may affect victims of professional accidents, including herpetologists, snake center assistants, veterinarians, biologists, students, collectors and those who raise snakes as pets, among others (Goldstein et al. 1981).

Thus, studies conducted to identify microorganisms in snakes are very important not only to expand knowledge of the bacteria that cohabit with these animals, but also to obtain understanding of the etiological agents of secondary infections resulting from accidents during handling. In this context, the profile of microbial sensitivity to drugs must be investigated to indicate adequate treatments in human accidents and ophidian bacterial infections.

Studies with Salmonella in snakes suggest that entry of infectious organisms into a collection is not confined to the addition of new reptiles but can also be due to prey species such as rodents. Ensuring the health of all animals entering a collection is paramount. Hygiene and perfect health of captive reptiles are all important also in venom production facilities (Williams 2008).

The present study aimed to evaluate and compare the aerobic microbiota of the oral cavity, cloaca and venom among three groups of Crotalus durissus terrificus snakes, recently caught from the wild and kept under quarantine (WQ), individual captivity (IC) and collective captivity (CC), and to determine the susceptibility of isolated bacteria to different antimicrobials.

\section{MATERIALS AND METHODS}

\section{Animals}

All of the 30 Crotalus durissus terrificus (South American rattlesnake) snakes utilized, 3 to 7 years old, were provided by the Center for Study of Venoms and Venomous Animals (CEVAP), of the São Paulo State University (Unesp) Botucatu (22 53' S, 48 27' W), São Paulo state, Brazil.

The 30 snakes were divided into three groups as follows: ten (8 female, 2 male) snakes from the wild caught and kept under quarantine (WQ), ten (females) maintained in individual captivity (IC) and ten (females) kept in collective captivity (CC). For more than one year before the beginning of the study, the IC group had been maintained in polypropylene boxes in a closed room at controlled temperature $\left(28^{\circ} \mathrm{C}\right)$ and humidity $(80 \%)$, while the CC group had been kept in a room measuring $4 \times 5 \mathrm{~m}$ partially covered by a roof $(2 \times 5 \mathrm{~m})$ with the other half exposed to open air. By contrast, the samples of the WQ group were collected on the same day that they were captured in the wild.

All animals, with inserted microchips, had access to water ad libitum and every 15 days were fed with mice raised exclusively for this purpose.

\section{Samples collected}

A total of 112 individual swabs was collected, 60 of which (53.10\%), 20 for each group, were of from oral mucosa; 30 swabs (26.55\%), 10 for each group, were from cloaca, and 22 swabs (20.35\%), 7 for WQ and IC and 8 for CC, were from venom. For this, the animals were sedated with $\mathrm{CO}_{2}$ and the material was immediately sent to laboratory in Stuart transport medium.

The samples were inoculated into BHI broth (Brain and Heart Infusion Broth) (BD Brazil, Becton, Dickinson and Company, Brazil), defibrinated bovine blood agar (5\%) (BD Brazil) and MacConkey agar (BD Brazil). They were then incubated at $37^{\circ} \mathrm{C}$ in aerobic conditions. Readings were accomplished at 24, 48 and 72 hours after inoculation. Microbial growth was analyzed by observing the morphological features, staining characteristics and biochemical tests of each bacterium.

\section{Antibiotic sensitivity tests}

Sensitivity to antibiotics was tested in vitro using Kirby-Bauer standardized single disc method ${ }^{5}$. The colonies were resuspended in $\mathrm{MH}$ broth (Muller Hinton Broth) (BD Brazil) and adjusted to a turbidity equivalent to 0.5 on the MacFarland scale. Next, a quantity of $100 \mathrm{ml}$ (about $10^{4}$ Colony Forming Units, CFU) of inoculum was seeded on HM agar plates with the handle Drigalsky and antimicrobial discs were distributed (amikacin, ampicillin, ceftiofur, chloranphenicol, enrofloxacin, gentamicin, norfloxacin, sulfazotrin, tobramycin) (BD Brazil). The plates were incubated in microaerophilic conditions at $37^{\circ} \mathrm{C}$ for 48 hours, when the sensitivity was read by measuring the bacterial growth inhibition halos. For quality control of the test samples, the pattern Staphylococcus aureus (ATCC 25923), Pseudomonas aeruginosa (ATCC 27853) and Escherichia coli (ATCC 25922) was used, along with the NCCLS susceptibility measure for aerobic organisms.

\section{Statistical analysis}

The statistical analysis - to compare the number of microorganisms isolated from the oral cavity, cloaca and venom among the three snake groups - was accomplished by the Kruskal-Wallis chi-square test $(P<0.05)$.

\section{RESULTS}

Table 1 shows the distribution of aerobic microorganisms isolated from each snake group, at different collection locations. Specifically, 38 samples were obtained from WQ group animals, resulting in 46 isolations, singly or in association, with 29 (63.04\%) microorganisms isolated

Table 1. Distribution of number of aerobic microorganisms isolated from three groups of Crotalus durissus terrificus snakes: Wild Quarantine (WQ); Collective Captivity (CC) and Individual Captivity (IC)

\begin{tabular}{ccccc}
\hline \multirow{2}{*}{ Groups } & \multicolumn{3}{c}{ Locations } & \multirow{2}{*}{ Total } \\
\cline { 2 - 3 } & Oral & Cloaca & Venom & \\
\hline WQ & $15(32.61 \%)$ & $29(63.04 \%)$ & $2(4.35 \%)$ & 46 \\
CC & $3(7.14 \%)$ & $38(90.48 \%)$ & $1(2.38 \%)$ & 42 \\
IC & $25(51.02 \%)$ & $21(42.86 \%)$ & $3(6.12 \%)$ & 49 \\
\hline
\end{tabular}

$\mathrm{X}^{2}=6.118 ; \mathrm{p}<0.05$ (WQ'“'CC'“IC). 
from the cloaca, 15 (32.61\%) from the oral cavity, and 2 $(4.35 \%)$ from the venom. Twelve species of microorganisms were found, with Pseudomonas aeruginosa, Proteus vulgaris and Morganella morganii being the most frequent. Also isolated were Salmonella enterica diarizonae IIlb, Escherichia coli, Salmonella spp., Enterobacter cloacae, Proteus spp., Citrobacter freundii, Edwardsiella tarda, Corynebacterium spp. and Micrococcus spp.

In CC group 36 samples were obtained, resulting in 42 isolations, singly or in association, with $38(90.48 \%)$ microorganisms isolated from the cloaca, $3(7.14 \%)$ from the oral cavity, and $1(2.38 \%)$ from the venom. Twelve microorganism species were encountered, of which Pseudomonas aeruginosa, Morganella morganii and Escherichia coli were the most prevalent. Also isolated were Proteus vulgaris, Salmonella enterica diarizonae IIIb Salmonella spp., Enterobacter cloacae, Citrobacter freundii, Corynebacterium spp., Salmonella enterica diarizonae Illa, Salmonella arizonae and Shigella spp.

The 38 samples obtained from IC group resulted in 49 isolations, singly or in association, with $21(42.86 \%)$ microorganisms isolated from the cloaca, $25(51.02 \%)$ from the oral cavity, and $3(6.12 \%)$ from the venom. Ten microorganism species were found, of which Pseudomonas aeruginosa, Salmonella enterica diarizonae IIla and Enterobacter cloacae were the most prevalent. Also were isolated Morganella morganii, Escherichia coli, Salmonella spp., Edwardsiella tarda, Corynebacterium spp., Streptococcus â-hemolítico and Proteus spp.

The bacterium most frequently isolated from the cloaca (Table 2) was Salmonella enterica (IIlb), which presented the highest sensitivity to gentamicin $(100 \%)$ and norfloxacin $(100 \%)$, but was only partially sensitive to ceftiofur $(71 \%)$ and $7 \%$ were resistant. Pseudomonas aeruginosa, isolated mostly from the cloaca and oral cavity, showed the highest sensitivity to amikacin (97\%) and gentamicin (94\%), and was least sensitive to Ceftiofur (70\%). Proteus vulgaris, isolated most from the oral cavity, was completely sensitive to amikacin (100\%), gentamicin (100\%) and norfloxacin $(100 \%)$, but was resistant to ceftiofur (100\%). Morganella morganii was isolated only from the cloaca and presented the highest sensitivity to amikacin $(100 \%)$, but was least sensitive to ampicillin (92\%) and ceftiofur (83\%). Enterobacter cloacae was isolated only from the cloaca and was completely sensitive to amikacin (100\%) and gentamicin $(100 \%)$. It showed total resistance to ampicillin (100\%), ceftiofur (100\%) and sulfazotrin (100\%).

\section{DISCUSSION}

Given the bacterial variation found in the bodies of snakes from various regions of the globe (Parrish et al. 1956, Garcia Lima \& Laure 1986), it is speculated that the rattlesnake oral microbiota and prey fecal microbiota are related, since these victims frequently defecate at the moment they are being ingested (Goldstein et al. 1979).

Environmental variation is another fundamental factor that may account for the microorganisms found. Captive snakes present different morbidity and mortality due to acquired, and sometimes communicable, infections.

The five microorganisms most frequently isolated from the three groups in this study were: Salmonella enterica diarizonae (IIlb), Pseudomonas aeruginosa, Proteus vulgaris, Morganella morganii and Enterobacter cloacae, which corroborates other studies (Arroyo et al. 1980, Draper et al. 1981, Jorge et al. 1990). It is well known that Salmonella spp. are routinely isolated from the gastroin-

Table 2. Isolation location and sensitivity profile of Salmonella enterica (IIlb), Pseudomonas aeruginosa, Proteus

vulgaris, Morganella morganii and Enterobacter cloacae isolated from Crotalus durissus terrificus snakes: Wild Quarantine (WQ); Collective Captivity (CC) and Individual Captivity (IC) against nine antimicrobials analyzed

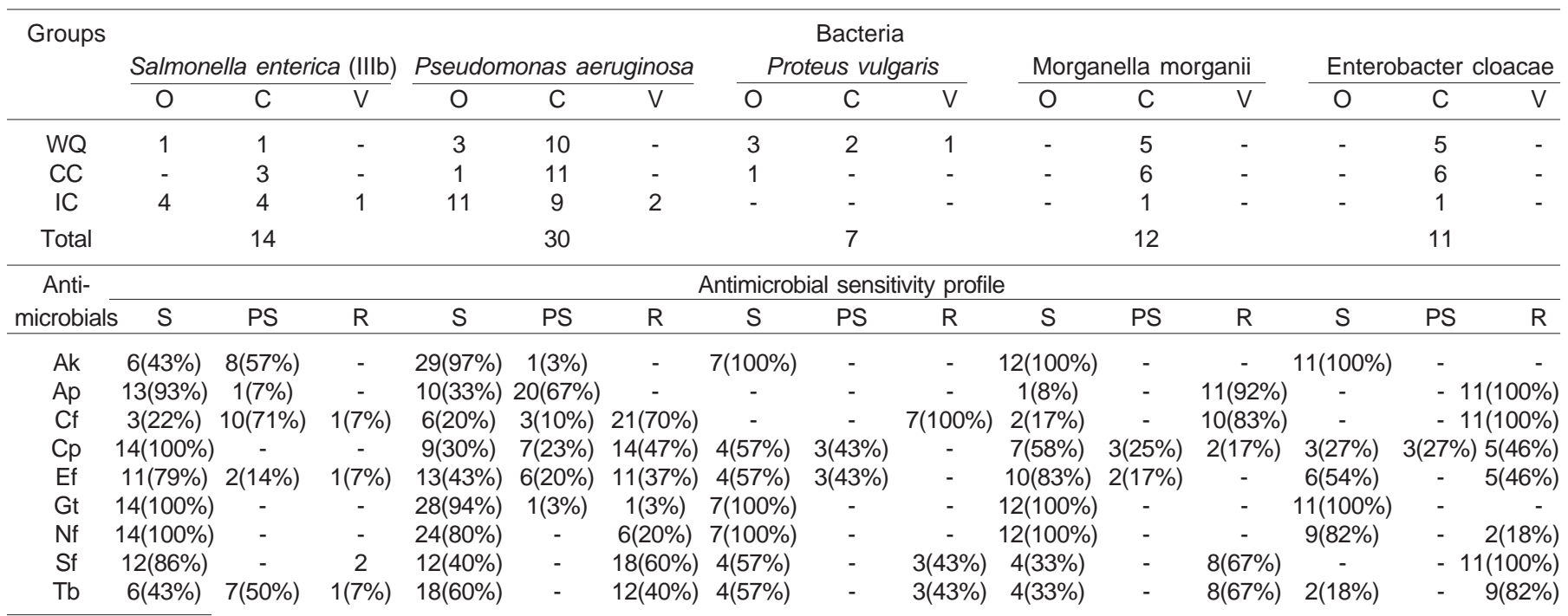

WQ = Wild Quarantine; CC = Collective Captivity; IC = Individual Captivity; O = Oral swab; C = Cloacal swab; V = Envenomated swab; $\mathrm{S}=\mathrm{Sensitive;}$ $\mathrm{PS}=$ Partially Sensitive; $\mathrm{R}=$ Resistant; $\mathrm{Ak}=$ Amikacin; $\mathrm{Ap}=$ Ampicillin; $\mathrm{Cf}=$ Ceftiofur; $\mathrm{Cp}=$ Chloranphenicol; Ef = Enrofloxacin; Gt $=\mathrm{Gentamicin} ; \mathrm{Nf}$ $=$ Norfloxacin; $\mathrm{Sf}=$ Sulfazotrin; $\mathrm{Tb}=$ Tobramycin. 
testinal tract of reptiles (Weiss et al. 1986, Woodward et al. 1997, Ramsay et al. 2002, Bemis et al. 2007, Fonseca et al. 2009), what represent a significant public health risk (Pasmans et al. 2008).

These findings highlight the necessities for cleaning lesions caused by snakebite accidents and for utilizing rigorous aseptic techniques. Moreover, this identification process can be useful for choosing an appropriate antibacterial therapy in patients who are the victims of such accidents, in agreement with other authors (Andrade et al. 1989, Jorge et al. 1994, Tagwireyi et al. 2001, Hejnar et al. 2007). A twelve year study by Avila-Agüero et al. 2001 , on snakebite accidents in children and adolescents concluded that bacterial infection was very common after the bites due to elevated bacterial colonization in the mouth of these snakes, favoring proliferation in damaged tissues.

The analysis of the microorganisms isolated in the present study demonstrated statistical difference among the three groups investigated. About $1 / 3(32.61 \%)$ of snakes recently caught in the wild (WQ group) presented multiple bacterial species in their oral cavities, indicating antibacterial therapy in rattlesnake accident cases, as suggested by Nishioka et al. 2000.

The great differences in the quantity and variation of bacteria isolated from the oral cavity between the CC group $(7.14 \%)$, maintained collectively, and the IC group $(51.02 \%)$, maintained in individual boxes, showed that open ventilated environments exposed to the sun, which enable thermoregulation, promote better oral health than restricted environments.

The microbiological populations of the mouth and venom of several poisonous North and South American wild snakes present equilibrium. However, the extensive contamination of the oral cavity of the animals maintained in captivity can be explained by their diet and by self conta-mination from their own feces which are often found in water troughs. But in external environments this contamination is minimized due to sanitary management through the use of limestone, hypochlorite and blowtorches (Ferreira Junior et al. 2009).

The results of sensitivity tests indicate the use of amikacin, gentamicin, norfloxacin, sulfazotrin and tobramycin against infections to ensure that animals destined for routine extractions produce high quality venom.

In the United Kingdom, few venomous reptiles keepers appreciate the risk from infectious agents to themselves and the animals in their care until it is too late. Hygiene and perfect health of captive reptiles are all important also in venom production facilities (Williams 2008).

In conclusion, the stress caused by alterations of habitat and behavior can constitute the greatest factor that predisposes snakes toward bacterial infections. A semiopen regime can provide full acclimation for the snakes maintained therein, since there is greater air circulation with different temperature gradients and no daily handling, which are essential to the health state of these animals.
The development of infections by opportunistic microorganisms also can result in non-utilization of the animal as a venom donor, resulting in greater expenditure of time, manual labor, specialized technique and maintenance material on the part of the snake house, as well as greater loss of animals.

Acknowledgements.- To Fernando José Paganini, the Microbiological Diagnostic Service of the Department of Veterinary Hygiene and Public Health, FMVZ, Unesp-Botucatu, SP, Brazil, as well as the Center for the Study of Venoms and Venomous Animals (CEVAP), Unesp-Botucatu, SP, and the State of São Paulo Research Foundation (FAPESP, Proc. 07/05159-7).

\section{REFERENCES}

Andrade J.G., Pinto R.N. \& Andrade A.L. 1989. Bacteriologic study of abscesses caused by bites of snakes of the genus Bothrops. Revta Inst. Med. Trop. 6:363-367.

Arroyo O., Bolaños R. \& Muñoz G., 1980. The bacterial flora of venoms and mouth cavities of Costa Rican snakes. Bull. Pan-Am. Hlth Org. 14:280-285.

Avila-Agüero M.L., Valverde K., Gutierrez J., Paris M.M. \& Faingezicht I. 2001. Venomous snakebites in children and adolescents: A 12 years retrospective review. J. Venom. Anim. Tox. 7:69-84.

Bemis D.A., Grupka L.M., Liamthong S., Folland D.W., Sykes IV J.M. \& Ramsay E.C. 2007. Clonal relatedness of Salmonella isolates associated with invasive infections in captive and wild-caught rattlesnakes. Vet. Microbiol. 120:300-307.

Blaylock R.S.M., 2001. Normal oral bacterial flora from some southern African snakes. Onderstepoort J. Vet. Res. 68:175-182.

Draper C.S., Walker R.D. \& Lawler H.E. 1981. Patterns of oral bacterial infection in captive snakes. J. Am. Vet. Med. Assoc. 179:1223-1226.

Ferreira Junior R.S., Biscola N.P., Campagner M.V. \& Barraviera B. 2009. How to raise snakes in captivity? Vet. Microbiol. In press. doi:10.1016/j.vetmic.2009.08.011

Fonseca M.G., Moreira W.M.Q., Cunha K.C., Ribeiro A.C.M.G. \& Almeida M.T.G. 2009. Oral microbiota of Brazilian captive snakes. J. Venom. Anim. Tox. incl. Trop. Dis. 15:54-60.

Garcia Lima E. \& Laure C.J. 1986. A study of bacterial contamination of rattlesnake venom. Revta Soc. Bras. Med. Trop. 20:19-21.

Goldstein E.J.C., Citron D.M., Gonzalez Russell H.E. \& Finegold S.M. 1979. Bacteriology of rattlesnake venom and implications for therapy. J. Infect. Dis. 140:818-821.

Goldstein E.J.C., Agyare E.O., Vagvolgyi A.E. \& Halpern M. 1981. aerobic bacterial oral flora of garter snakes: Development of normal flora and pathogenic potential for snakes and humans. J. Clin. Microbiol. 13:954956.

Hejnar P., Bardon J., Sauer P. \& Kolar M. 2007. Stenotrophomonas maltophilia as a part of normal oral bacterial flora in captive snakes and its susceptibility to antibiotics. Vet. Microbiol. 121:357362.

Jorge M.T., Mendonça J.S., Ribeiro L.A., Da Silva M.L.R., Kusano E.J.U. \& Cordeiro C.L. 1990. Flora bacteriana da cavidade oral, presas e veneno de Bothrops jararaca: Possível fonte de infecção no local da picada. Revta Inst. Med. Trop. 32:6-10.

Jorge M.T., Adriano L., Silva M.L., Uro E.J. \& Silva J. 1994. Microbiological studies of abscesses complicating Bothrops snake bite in humans: A prospective study. Toxicon 6:743-748.

Nishioka S.A., Jorge M.T., Silveira P.V.P. \& Ribeiro L.A. 2000. South American rattlesnake bite and soft-tissue infection: Report of a case. Revta Soc. Bras. Med. Trop. 33:401-402.

Parrish H.M., Maclaurin A.W. \& Tuttle R.L. 1956. North American pit 
vipers: Bacterial flora of the mouths and venom glands. Virg. Med. Monthly 83:383-385.

Pasmans F., Blahak S., Martel A. \& Pantchev N. 2008. Introducing reptiles into a captive collection: The role of the veterinarian. Vet. J. 175:53-68.

Ramsay E.C., Daniel G.B., Tryon B.W., Merryman J.I., Morris P.J. \& Bemis D.A. 2002. Osteomyelitis associated with Salmonella enterica ss arizonae in a colony of ridgenose rattlesnakes (Crotalus willardi). J. Zoo Wildl. Med. 33:301-310.

Soveri T. \& Seuna E.R. 1986. Aerobic oral bacteria in healthy captive snakes. Acta Vet. Scand. 27:172-181.

Tagwireyi D.D., Ball D.E. \& Nhachi C.F.B. 2001. Routine prophylactic antibiotic use in the management of snakebite. BMC Clin. Pharmacol. $1: 4$.

Weiss S.H., Blaser M.J., Paleologo F.P., Black, R.E. McWhorter A.C., Asbury M.A., Carter G.P., Feldman R.A. \& Brenner D.J. 1986. Occurrence and distribution of serotypes of the Arizona subgroup of Salmonella strains in the United States from 1967 to 1976. J. Clin. Microbiol. 231056-1064.

Williams D.L. 2008. Healthy herpetology: The role of the veterinarian in reptile prophylaxis. Vet. J. 175:16-17.

Woodward D.L., Khakhria R. \& Johnson W.M. 1997. Human salmonellosis associated with exotic pets. J. Clin. Microbiol. 35:27862790. 